\title{
SUMBER-SUMBER ILMU PENGETAHUAN DALAM AL QUR'AN DAN HADITS
}

\author{
Sayid Qutub \\ Jurusan Marketing Communication, Fakultas Ekonomi dan Komunikasi, BINUS University \\ Jln. K.H. Syahdan No. 9, Palmerah, Jakarta Barat 11480
}

\begin{abstract}
From the beginning, Islam had given gratitude towards knowledge. One enlightenment that Islam has brought to humanity is scientific thinking refered to Alquran and Hadits. The awareness of Muslim scientist based on Alquran and Hadits produced the biggest achievement of knowledge. Other characteristics taught by Alquran and Hadits to the Muslims are open-minded, that allowed them to get knowledge from other civilization with no justification. The purpose of this article is to establish understanding of Alquran and Hadits in thematic analysis, especially about knowledge. This article is written based on literature review about related knowledge and the interpretation of Alquran and Hadits (tafsir). It is known that there is no standalone or separated knowledge from Islamic epistemology; the knowledge is the description of devine affirmation, absolute fact. This article is expected to be a filter in anticipating negative influence from knowledge and technology development.
\end{abstract}

Keywords: knowledge, Alquran, Hadits, Islam

\begin{abstract}
ABSTRAK
Sejak awal kelahirannya, Islam sudah memberikan penghargaan yang begitu besar kepada ilmu. Salah satu pencerahan yang dibawa oleh Islam bagi kemanusiaan adalah pemikiran secara ilmiah yang merujuk kepada Alquran dan Hadits. Kesadaran para ilmuan muslim yang bersumber dari Alquran dan Hadits memicu pencapaian terbesar dalam ilmu pengetahuan. Sifat lain yang diajarkan oleh Alquran dan Hadits kepada kaum muslim adalah keterbukaan pikiran, yang memungkinkan mereka mendapatkan ilmu pengetahuan dari peradaban lain tanpa prasangka. Tujuan penulisan ini sebagai salah satu upaya membumikan Alquran dan Hadits dengan mengkaji secara tematik khususnya tentang ilmu pengetahuan. Artikel ini ditulis berdasarkan studi pustaka mengenai ilmu terkait serta tafsir Alquran dan Hadits. Diketahui bahwa dalam Islam tidak ada satupun ilmu yang berdiri sendiri dan terpisah dari bangunan epistemologis Islam, ilmu-ilmu tersebut tidak lain merupakan bayan atau penjelasan yang mengafirmasi wahyu, yang kebenarannya pasti. Hasil penelitian ini diharapkan dapat dijadikan sebagai filter dalam mengantisipasi pengaruh negatif dari perkembangan ilmu pengetahuan dan teknologi.
\end{abstract}

Kata kunci: ilmu pengetahuan, Alquran, hadits, Islam 


\section{PENDAHULUAN}

Sejak awal kelahirannya, Islam sudah memberikan penghargaan yang begitu besar kepada ilmu. Sebagaimana sudah diketahui, bahwa Nabi Muhammad SAW ketika diutus oleh Allah SWT sebagai Rasul, hidup dalam masyarakat yang terbelakang, dimana paganisme tumbuh menjadi sebuah identitas yang melekat pada masyarakat Arab masa itu. Kemudian Islam datang menawarkan cahaya penerang, yang mengubah masyarakat Arab jahiliyah menjadi masyarakat yang berilmu dan beradab. Salah satu pencerahan yang dibawa oleh Islam bagi kemanusiaan adalah pemikiran secara ilmiah, masyarakat Arab dan Timur tengah pra Islam tidak memperdulikan persoalan-persoalan mengenai alam semesta, bagaimana alam tercipta dan bagaimana alam bekerja, maka dari sinilah mereka belajar merenungi pertanyaan-pertanyaan ini dan untuk mencari jawabannya tentang itu semua, mereka merujuk kepada Alquran dan Hadits. Di dalam Alquran (QS Ali-Imran: 190-191), Allah memerintahkan memikirkan bagaimana langit dan bumi tercipta, cara fikir ini menggerakkan bangkitnya ilmu pengetahuan dalam peradaban Islam. Ini adalah pengembangan ilmu pengetahuan yang istimewa dalam sejarah dunia, terutama tentang alam semesta.

Menurut Al-Indunisi (2008), Baghdad menjadi ibukota ilmu pengetahuan dalam imperium Islam, selain menjadi ibu kota, Baghdad menjadi pusat kumpulnya para peneliti, illmuan dan filosof. Yang terkenal di sana pada saat itu adalah terungkapnya rahasia alam semesta yang Allah ciptakan. Kesadaran para ilmuan muslim yang bersumber dari Alquran dan Hadits memicu pencapaian terbesar dalam ilmu pengetahuan, sesuatu yang belum pernah terjadi sebelumnya, sifat lain yang diajarkan oleh Al- Qur'an dan Hadits kepada kaum muslim adalah keterbukaan fikiran, yang memungkinkan mereka mendapatkan ilmu pengetahuan dari peradaban lain tanpa prasangka.

Karya-karya kaum muslim sangat mengagumkan dan mempunyai andil yang sangat besar dalam penelitian, pengamatan, percobaan dan perhitungan. Sebagai contoh, sistem desimal yang sekarang digunakan diseluruh dunia dikembangkan oleh ahli matematika muslim. Menurut Gordon (2008), aljabar dan trigonometri adalah temuan pakar matematika muslim. Sejumlah prestasi kaum muslimin yang paling memukau adalah dibidang kedokteran, dimasa ketika orang Eropa menganggap penyakit disebabkan oleh roh jahat.

Pengamatan dokter-dokter muslim terhadap anatomi manusia sangatlah tepat sehingga hasilnya dijadikan buku-buku rujukan di sekolah-sekolah kedokteran Eropa selama lebih dari enam abad silam. Dokter-dokter Islam juga mengukur denyut nadi pasien ketika sedang memeriksa mereka, dan ini dilakukan berabad-abad sebelum orang Eropa. Ilmuan muslim menemukan sejumlah penemuan-penemuan yang sangat penting dalam bidang optik dan cahaya. Orang yang pertama yang meggambarkan anatomi mata dengan sangat terperinci adalah ahli optik muslim yaitu Ibnu Al Haitsam, penelitiannya yang diakui dalam bidang lensa membuka jalan bagi penemuan kamera. Dokter-dokter muslim juga menemukan penyebab kerusakan penglihatan dan melakukan operasi katarak yang berhasil beberapa abad sebelum Eropa. Warisan ilmu pengetahuan Islam menjadi sumber pencerahan Eropa (Abqary, 2010).

Pada dasarnya hakikat ilmu pengetahuan adalah untuk mencari kebenaran secara ilmiah, namun dalam Alquran dan Hadits hakikat ilmu pengetahuan bukan semata-mata untuk mencari kebenaran yang bersifat ilmiah, melainkan untuk mencari-tanda-tanda, kebajikan-kebajikan dan rahmah untuk itu apakah hakikat ilmu pengetahuan sebenarnya?

Alquran bukan merupakan penghambat perkembangan ilmu pengetahuan, tidak sedikit ayatayat Alquran dan Hadits yang mendorong manusia untuk mengembangkan ilmu pengetahuan, oleh karena itu bagaimana peran Alquran dan Hadits dalam perkembangan ilmu pengetahuan? 
Bagaimanapun ilmu pengetahuan harus digunakan, dalam penggunaan ini disatu sisi ilmu pengetahuan bebas dari nilai (value free), disisi lain Alquran dan Hadits menekankan bahwa segala bentuk kegiatan manusia harus dikaitkan dengan nilai ibadah; bagaimana pandangan Alquran dan Hadits terhadap penggunaan ilmu pengetahuan?

Tujuan penelitian ini adalah: (1) sebagai salah satu upaya membumikan Alquran dan Hadits dengan mengkaji secara tematik khusunya tentang ilmu pengetahuan; (2) menambah khazanah intelektualitas bagi ummat Islam yang selalu ingin menemukan kejayaannya kembali dengan mengkaji ulang konsep ilmu pengetahuan dan teknologi; (3) di tengah era globalisasi, ilmu pengetahuan dan teknologi berkembang begitu cepatnya yang membawa perubahan sosial dan pergeseran nilai. Hasil penelitian ini diharapkan dapat dijadikan sebagai filter dalam mengantisifasi pengaruh negatif dari perkembangan ilmu pengetahuan dan teknologi.

\section{PEMBAHASAN}

\section{Ilmu Pengetahuan dalam Al Qur'an}

Ilmu pengetahuan adalah merupakan salah satu isi pokok kandungan kitab suci Alquran. Bahkan kata 'ilm itu sendiri disebut dalam Alquran sebanyak 105 kali, tetapi dengan kata jadiannya ia disebut lebih dari 744 kali (Rahardjo, 2002). yang memang merupakan salah satu kebutuhan agama Islam, betapa tidak setiap kali umat Islam ingin melaksanakan ibadah selalu memerlukan penentuan waktu dan tempat yang tepat, umpamanya melaksanakan shalat, menentukan awal bulan Ramadhan, pelaksanaan haji, semuanya punya waktu-waktu tertentu. Dalam menentukan waktu yang tepat diperlukan ilmu astronomi. Maka dalam Islam pada abad pertengahan dikenal istilah sains mengenai waktu-waktu tertentu (Turner, 2004). Banyak lagi ajaran agama yang pelaksanaannya sangat terkait erat dengan sains dan teknologi, seperti menunaikan ibadah haji, berdakwah, semua itu membutuhkan kendaraan sebagai alat transportasi. Allah telah meletakkan garis-garis besar sains dan ilmu pengetahuan dalam Alquran, manusia hanya tinggal menggali, mengembangkan konsep dan teori yang sudah ada, antara lain sebagaimana terdapat dalam QS. Ar-Rahman ayat 33 di bawah ini.

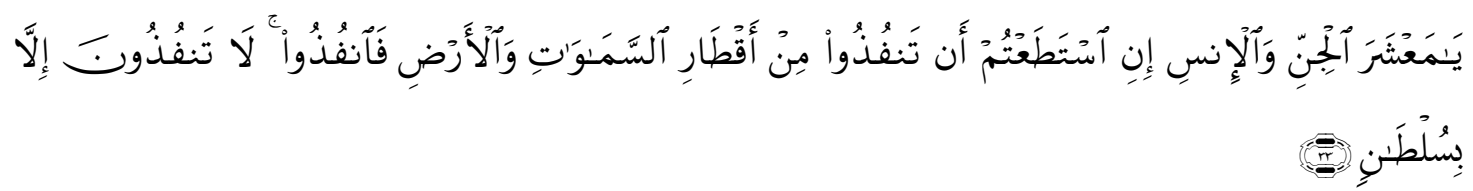

Artinya: "Hai jama'ah jin dan manusia, jika kamu sanggup menembus (melintasi) penjuru langit dan bumi, Maka lintasilah, kamu tidak dapat menembusnya kecuali dengan kekuatan.”

Ayat di atas pada masa empat belas abad yang silam telah memberikan isyarat secara ilmiyah kepada bangsa Jin dan Manusia, bahwasanya mereka telah dipersilakan oleh Allah untuk mejelajah di angkasa luar asalkan saja mereka punya kemampuan dan kekuatan (sulthan). Kekuatan yang dimaksud di sini sebagaimana di tafsirkan para ulama adalah ilmu pengetahuan atau sains dan teknologi, hal ini telah terbukti di era modern sekarang ini, dengan di temukannya alat transportasi yang mampu menembus luar angkasa, bangsa-bangsa yang telah mencapai kemajuan dalam bidang sains dan teknologi telah berulang kali melakukan pendaratan di Bulan, Pelanet Mars, Jupiter dan planet-pelanet lainnya.

Kemajuan yang telah diperoleh oleh bangsa-bangsa yang maju (bangsa barat) dalam bidang ilmu pengetahuan, sains dan teknologi di abad modern ini, sebenarnya merupakan kelanjutan dari tradisi ilmiah yang telah dikembangkan oleh ilmuan-ilmuan muslim pada abad pertengahan atau dengan kata lain ilmuan muslim banyak memberikan sumbangan kepada ilmuan barat, hal ini 
sebagaimana diungkapkan oleh Yatim (1997) dalam bukunya Sejarah Perdaban Islam: "Kemajuan Barat pada mulanya bersumber dari peradaban Islam yang masuk ke Eropa melalui Spanyol” (p. 2).

Hal ini diakui oleh sebagian mereka. Sains dan teknologi baik itu yang ditemukan oleh ilmuan muslim maupun oleh ilmuan barat pada masa dulu, sekarang dan yang akan datang, semua itu bukti kebenaran informasi yang terkandung di dalam Alquran, karena jauh sebelum peristiwa penemuanpenemuan itu terjadi, Alquran telah memberikan isyarat-isyarat tentang hal itu dan ini termasuk bagian dari kemukjizatan Alquran, dimana kebenaran yang terkandung di dalamnya selalu terbuka untuk dikaji, didiskusikan, diteliti, diuji dan dibuktikan secara ilmiah oleh siapa pun.

Alquran adalah kitab induk, rujukan utama bagi segala rujukan, sumber dari segala sumber, basis bagi segala sains dan ilmu pengetahuan. Alquran adalah buku induk ilmu pengetahuan, di mana tidak ada satu perkara apapun yang terlewatkan (Kartanegara, 2006), semuanya telah diatur di dalamnya, baik yang berhubungan dengan Allah (hablum minallah) sesama manusia (hablum minannas) alam, lingkungan, ilmu akidah, ilmu sosial, ilmu alam, ilmu emperis, ilmu agama, umum dan sebagainya (dalam QS Al An’am: 38).

Lebih lanjut Baiquni (1997) mengatakan bahwa sebenarnya segala ilmu yang diperlukan manusia itu tersedia di dalam Alquran (p. 17). Salah satu kemukjizatan (keistimewaan) Alquran yang paling utama adalah hubungannya dengan ilmu pengetahuan, begitu pentingnya ilmu pengetahuan dalam Alquran sehingga Allah menurunkan ayat yang pertama kali QS. Al-‘Alaq: 1-5, yaitu:

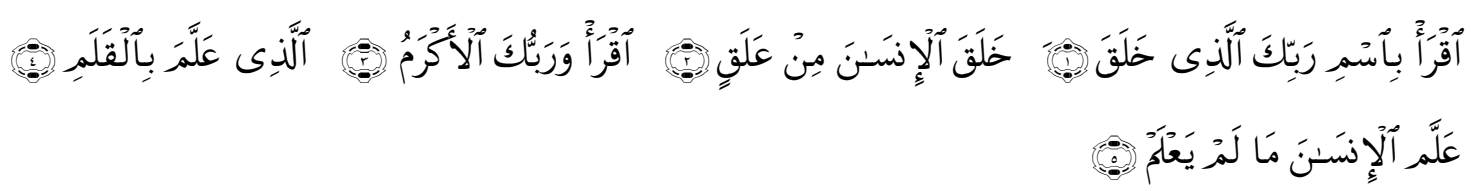

Artinya: “Bacalah dengan (menyebut) nama Tuhanmu yang Menciptakan, Dia telah menciptakan manusia dari segumpal darah. Bacalah, dan Tuhanmulah yang Maha pemurah, yang mengajar (manusia) dengan perantaran kalam, Dia mengajar kepada manusia apa yang tidak diketahuinya.”

\section{Pentingnya Belajar Menurut Al Qur'an dalam Surat Al-Alaq Ayat 1-5}

Surat Al-Alaq (Iqra') termasuk ayat Al Qur'an pertama yang diturunkan, termasuk ayat makiyyah, terdiri dari 19 ayat, 93 kalimat dan 280 huruf. Dalam Surat Al Alaq dapatlah di lihat suatu gambaran yang hidup mengenai suatu peristiwa terbesar yang pernah terjadi pada sejarah manusia, yaitu pertemuan Nabi Muhammad SAW dengan Malaikat Jibril untuk pertama kali di Gua Hiro' dan penerimaan wahyu yang pertama setelah Nabi berusia 40 tahun.

Bagian pertama Surat Al-Alaq ini mengarahkan Nabi Muhammad SAW kepada Allah agar beliau berkomunikasi dengan Allah dan beliau dengan nama Allah membaca ayat-ayat Alquran yang diterima melalui wahyu/Jibril (bukan membaca tulisan di atas kertas, sebab ia adalah ummi/tidak pandai baca tulis). Sebab dari Allah-lah asal mula segala makhluk dan kepadanya pulalah semua akan kembali.

Wahyu pertama itu juga mengingatkan, bahwa Allah telah memuliakan/menjunjung tinggi martabat manusia melalui baca. Artinya dengan proses belajar mengajar itu manusia dapat menguasai ilmu-ilmu pengetahuan dan dengan ilmu-ilmu pengetahuan ini manusia dapat mengetahui rahasia alam semesta yang sangat bermanfaat bagi kesejahteraan hidupnya. Padahal manusia itu dijadikan oleh Allah dari segumpal darah yang melekat dirahim ibu. Surat Al-Alaq ayat 1-5 diturunkan sewaktu 
Rasulullah SAW berkhalwat di Gua Hiro, ketika itu beliau berusia 40 tahun. Ayat-ayat pertama yang diturunkan sekaligus merupakan tanda pengangkatan Nabi Muhammad SAW sebagai Rasul Allah.

Surat Al-Alaq ayat 1-5 mengandung pengertian bahwa untuk memahami segala macam ilmu pengetahuan, seseorang harus pandai dalam membaca. Dalam membaca itu harus didahului dengan menyebut nama Tuhan; yakni dengan membaca "BasmAllah" terlebih dulu dan ingat akan kekuasaan yang dimiliki-Nya, sehingga ilmu yang diperoleh dari membaca itu, akan menambah dekatnya hubungan manusia dengan khaliq-nya.

Allah SWT menjelaskan bahwa Dia-lah yang menciptakan manusia dari segumpal darah dan kemudian menjadikan makhluk yang paling mulia. Ini menunjukkan betapa Maha Kuasanya Allah SWT. Pada ayat berikutnya Allah SWT Mengulang untuk memerintahkan membaca, dalam rangka untuk mengetahui kemuliaan Allah Yang Maha Pemurah. Dengan limpahan karunia-Nya, Dia juga mengajarkan kepada manusia kemampuan membaca dan kemampuan menggunakan pena (kemampuan baca tulis), yang menyebabkan manusia dapat mempelajari berbagai persoalan, sehingga manusia dapat menguasai berbagai ilmu yang diperlukan dalam hidupnya.

Surat Al-Alaq ayat 1-5 mengandung perintah membaca, membaca berarti berfikir secara teratur atau sitematis dalam mempelajari firman dan ciptaan-Nya, berfikir dengan menkorelasikan antara ayat qauliah dan kauniah manusia akan mampu menemukan konsep-konsep sains dan ilmu pengetahuan. Bahkan perintah yang pertama kali dititahkan oleh Allah kepada Nabi Muhammada SAW dan umat Islam sebelum perintah-perintah yang lain adalah mengembangkan sains dan ilmu pengetahuan serta bagaimana cara mendapatkannya. Tentu ilmu pengetahuan diperoleh di awali dengan cara membaca, karena membaca adalah kunci dari ilmu pengetahuan, baik membaca ayat qauliah maupun ayat kauniah, sebab manusia itu lahir tidak mengetahui apa-apa, pengetahuan manusia itu diperoleh melalui proses belajar dan melalui pengalaman yang dikumpulkan oleh akal serta indra pendengaran dan penglihatan demi untuk mencapai kejayaan, kebahagian dunia dan akhirat (Sarwar, 1994).

Menurut DEPAG (2000), dalam Alquran terdapat kurang lebih 750 ayat rujukan yang berkaitan dengan ilmu pengetahuan sementara tidak ada agama atau kebudayaan lain yang menegaskan dengan begitu tegas akan kepentingan ilmu dalam kehidupan manusia. Ini membuktikan bahwa betapa tingginya kedudukan sains dan ilmu pengetahuan dalam Alquran (Islam). Alquran selalu memerintahkan kepada manusia untuk mendayagunakan potensi akal, pengamatan, pendengaran, semaksimal mungkin (Hasan, 2005).

Islam adalah satu-satunya agama di dunia yang sangat (bahkan paling) empatik dalam mendorong umatnya untuk menuntut ilmu, bahkan Alquran itu sendiri merupakan sumber ilmu dan sumber inspirasi berbagai disiplin ilmu pengetahuan sains dan teknologi. Betapa tidak, Alquran sendiri mengandung banyak konsep-konsep sains, ilmu pengetahuan dan teknologi serta pujian terhadap orang-orang yang berilmu.

Dalam QS. Al-Mujaadilah ayat 11, Allah SWT berfirman:

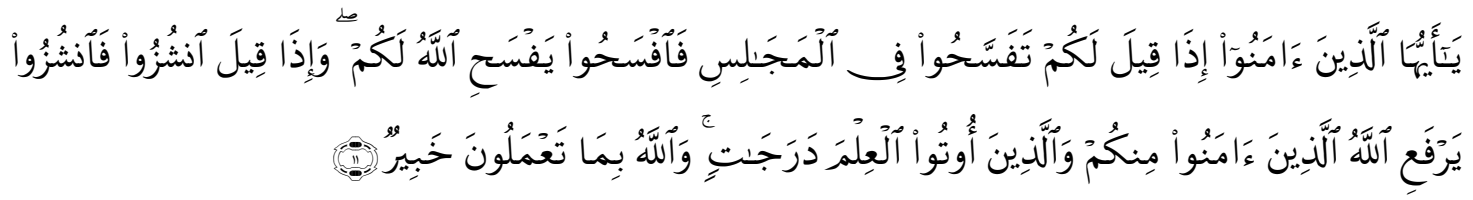

Artinya: "Hai orang-orang beriman apabila kamu dikatakan kepadamu: "Berlapang-lapanglah dalam majlis", Maka lapangkanlah niscaya Allah akan memberi kelapangan untukmu. dan apabila dikatakan: 
"Berdirilah kamu", Maka berdirilah, niscaya Allah akan meninggikan orang-orang yang beriman di antaramu dan orang-orang yang diberi ilmu pengetahuan beberapa derajat. dan Allah Maha mengetahui apa yang kamu kerjakan."

Dalam Tasmara (2004), kita dapat melihat dengan jelas bahwa Islam merupakan agama yang sangat maju dalam bidang ilmu pengetahuan, jadi Islam bukanlah sebatas ibadah dan shalat saja tetapi Islam adalah kaffah (menyeluruh). Menurut Ali Syariati (dalam Tasmara, 2004), Alquran merupakan firman Allah yang sangat komprehensif, yang menjadi sumber inspirasi bagi manusia dalam semua lini kehidupan. Hal ini dapat dilihat dari klasifikasi Alquran yang dibuat olehnya.

Tabel 1 Klasifikasi Alquran

\begin{tabular}{clcc}
\hline NO & KLASIFIKASI SURAT & JUMLAH SURAT & PROSENTASE \\
\hline 1 & Fenomena Alam dan Materi & 32 & $26.66 \%$ \\
2 & Aqidah dan Aliran Pemikiran & 29 & $24.14 \%$ \\
3 & Sosial dan Politik & 27 & $22.5 \%$ \\
4 & Sejarah dan Filsafat Sejarah & 17 & $14.14 \%$ \\
5 & Perilaku dan Akhlak & 4 & $3.3 \%$ \\
6 & Masalah Harta & 4 & $3.3 \%$ \\
7 & Ibadah dan Syiar Agama & 2 & $1.7 \%$ \\
\hline
\end{tabular}

Sumber: Tasmara (2004)

Prinsip tauhid di dalam Islam, menegaskan bahwa semua yang ada berasal dan atas izin Allah SWT. Dia-lah Allah SWT yang Maha Mengetahui segala sesuatu. Konsep kekuasaan-Nya juga meliputi pemeliharaan terhadap alam yang Dia ciptakan. Konsep yang mengatakan bahwa Allah SWT lah yang mengajarkan manusia disebutkan dalam Al-Quran.

QS Al Baqarah ayat 31:

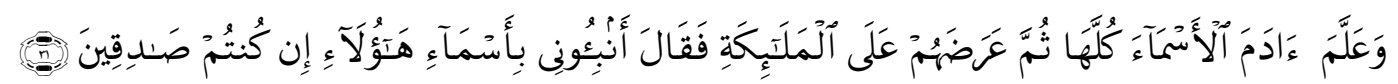

Artinya: "Dan Dia mengajarkan kepada Adam Nama-nama (benda-benda) seluruhnya, kemudian mengemukakannya kepada Para Malaikat lalu berfirman: "Sebutkanlah kepada-Ku nama benda-benda itu jika kamu memang benar orang-orang yang benar!"

QS Al Baqarah ayat 239:

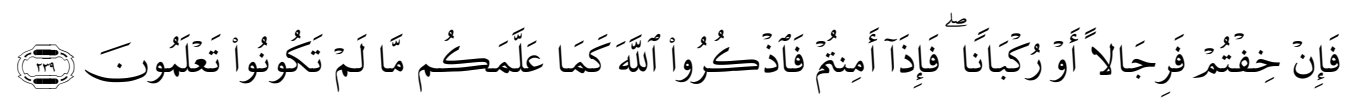

Artinya: "Jika kamu dalam Keadaan takut (bahaya), Maka Shalatlah sambil berjalan atau berkendaraan. kemudian apabila kamu telah aman, Maka sebutlah Allah (shalatlah), sebagaimana Allah telah mengajarkan kepada kamu apa yang belum kamu ketahui.” 
QS Ar-Rahman ayat 2:

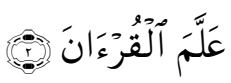

Artinya: "Yang telah mengajarkan Alquran."

QS. Al-A'laq ayat 4-5:

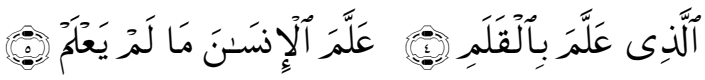

Artinya: "Yang mengajar (manusia) dengan perantaran kalam. Dia mengajar kepada manusia apa yang tidak diketahuinya."

Sumber-sumber pengetahuan lain selain yang diwahyukan langsung misalnya fenomena alam, psikologi manusia, dan sejarah. Alquran menggunakan istilah ayat (tanda) untuk menggambarkan sumber ilmu berupa fenomena alam dan psikologi, dalam ayat-ayat berikut.

QS Al Baqarah ayat 164:

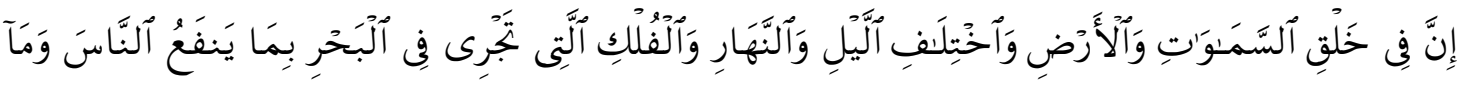

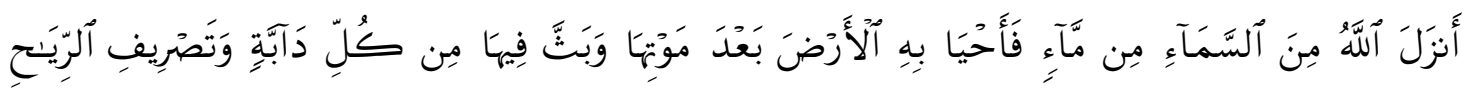

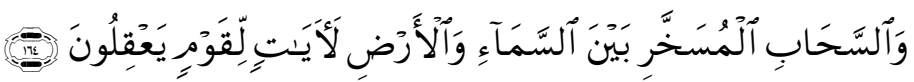

Artinya: "Sesungguhnya dalam penciptaan langit dan bumi, silih bergantinya malam dan siang, bahtera yang berlayar di laut membawa apa yang berguna bagi manusia, dan apa yang Allah turunkan dari langit berupa air, lalu dengan air itu Dia hidupkan bumi sesudah mati (kering)-nya dan Dia sebarkan di bumi itu segala jenis hewan, dan pengisaran angin dan awan yang dikendalikan antara langit dan bumi; sungguh (terdapat) tanda-tanda (keesaan dan kebesaran Allah) bagi kaum yang memikirkan."

QS Asy Syuura ayat 53:

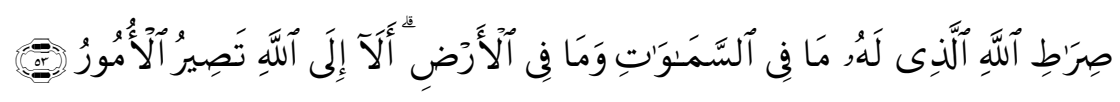

Artinya: "(yaitu) jalan Allah yang Kepunyaan-Nya segala apa yang ada di langit dan apa yang ada di bumi. Ingatlah, bahwa kepada Allah-lah kembali semua urusan."

Untuk sumber ilmu berupa fenomena sejarah, Alquran menggunakan istilah 'ibrah (pelajaran, petunjuk) yang darinya bisa diambil pelajaran moral dalam ayat berikut.

QS Yusuf ayat 111:

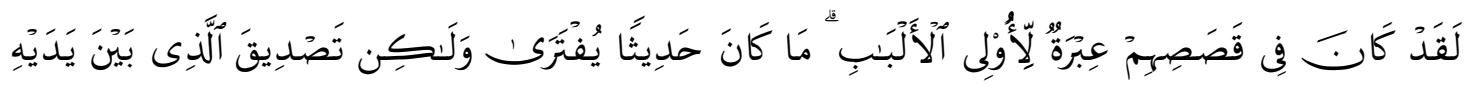

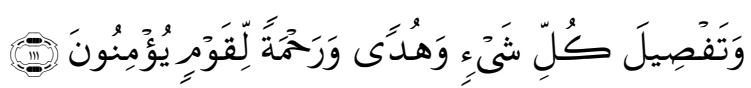


Artinya: "Sesungguhnya pada kisah-kisah mereka itu terdapat pengajaran bagi orang-orang yang mempunyai akal. Al Quran itu bukanlah cerita yang dibuat-buat, akan tetapi membenarkan (kitabkitab) yang sebelumnya dan menjelaskan segala sesuatu, dan sebagai petunjuk dan rahmat bagi kaum yang beriman.”

Sebagai akibat wajar dari otoritas ketuhanan-Nya, Alquran, di samping menunjukkan sumbersumber pengetahuan eksternal, Alquran juga merupakan sumber utama pengetahuan (Hafidhuddin, 1998). Dalam Islam, pencarian pengetahuan oleh seseorang bukanlah sesuatu yang tidak mungkin, tetapi harus, dan dianggap sebagai kewajiban bagi semua Muslim yang bertanggung jawab. Kedudukan ini berbeda dengan sikap skeptis Yunani dan Sophis, yang menganggap pengetahuan hanya imajinasi kosong.

Dalam bahasa Arab, pengetahuan digambarkan dengan istilah al-ilm, al-ma'rifah dan alsyu'ur. Namun, dalam pandangan dunia Islam, yang pertamalah yang terpenting, karena ia merupakan salah satu sifat Allah SWT. Al-ilm berasal dari akar kata l-m dan diambil dari kata 'alamah, yang berarti tanda, simbol, atau lambang, yang dengannya sesuatu itu dapat dikenal. Tapi 'alamah juga berarti pengetahuan, lencana, karakteristik, petunjuk dan gejala. Karenanya ma'lam (jamak ma'alim) berarti petunjuk jalan, atau sesuatu yang menunjukkan dirinya atau dengan apa seseorang ditunjukkan. Hal yang sama juga pada kata alam berarti rambu jalan sebagai petunjuk. Di samping itu, bukan tanpa tujuan Alquran menggunakan istilah ayat baik terhadap wahyu, maupun terhadap fenomena alam. Pengertian ayat (dan juga ilm, alam, dan 'alama) di dalam Alquran tersebut yang menyebabkan Nabi Muhammad SAW mengutuk orang-orang yang membaca Surat Ali Imran ayat 190-195 yang secara jelas menggambarkan karakteristik orang-orang yang mambaca, mengingat ayat-ayat Allah SWT di muka bumi tanpa mau merenungkan maknanya.

QS Ali Imran ayat 190-195:

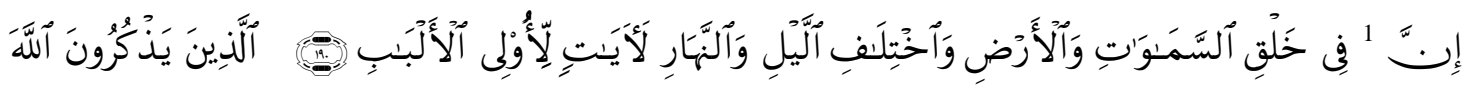

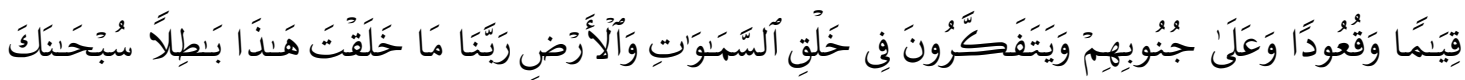

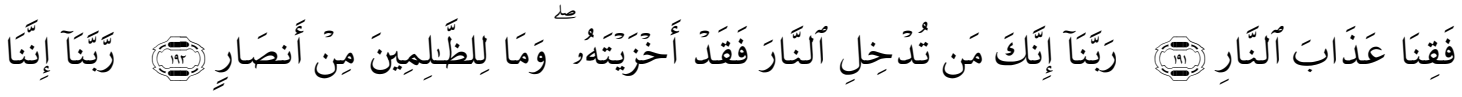

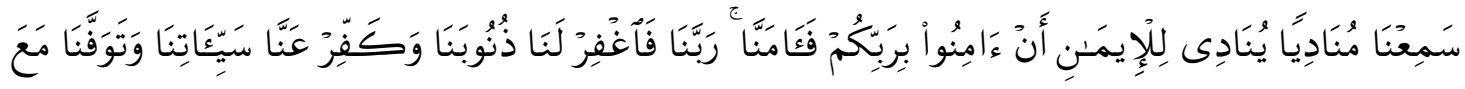

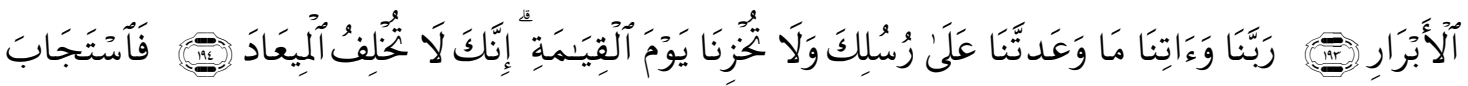

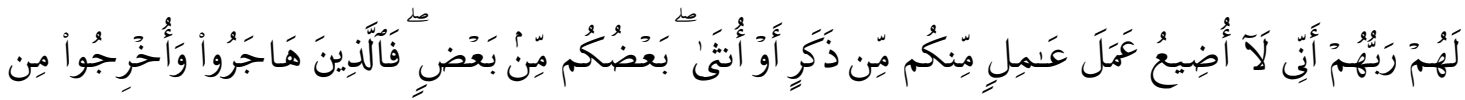

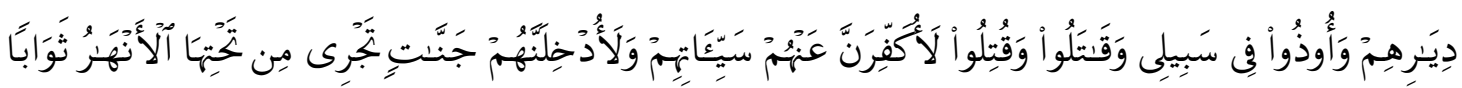

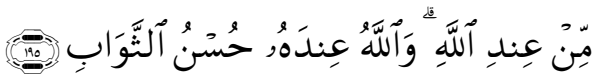

Artinya: "Sesungguhnya dalam penciptaan langit dan bumi, dan silih bergantinya malam dan siang terdapat tanda-tanda bagi orang-orang yang berakal, (yaitu) orang-orang yang mengingat Allah sambil berdiri atau duduk atau dalam keadan berbaring dan mereka memikirkan tentang penciptaan langit dan bumi (seraya berkata): "Ya Tuhan Kami, Tiadalah Engkau menciptakan ini dengan sia-sia, Maha suci Engkau, Maka peliharalah Kami dari siksa neraka. Ya Tuhan Kami, Sesungguhnya Barangsiapa yang Engkau masukkan ke dalam neraka, Maka sungguh telah Engkau hinakan ia, dan 
tidak ada bagi orang-orang yang zalim seorang penolongpun. Ya Tuhan Kami, Sesungguhnya Kami mendengar (seruan) yang menyeru kepada iman, (yaitu): "Berimanlah kamu kepada Tuhanmu", Maka Kamipun beriman. Ya Tuhan Kami, ampunilah bagi Kami dosa-dosa Kami dan hapuskanlah dari Kami kesalahan-kesalahan Kami, dan wafatkanlah Kami beserta orang-orang yang banyak berbakti. Ya Tuhan Kami, berilah Kami apa yang telah Engkau janjikan kepada Kami dengan perantaraan Rasulrasul Engkau. dan janganlah Engkau hinakan Kami di hari kiamat. Sesungguhnya Engkau tidak menyalahi janji.". Maka Tuhan mereka memperkenankan permohonannya (dengan berfirman): "Sesungguhnya aku tidak menyia-nyiakan amal orang-orang yang beramal di antara kamu, baik lakilaki atau perempuan, (karena) sebagian kamu adalah turunan dari sebagian yang lain. Maka orangorang yang berhijrah, yang diusir dari kampung halamannya, yang disakiti pada jalan-Ku, yang berperang dan yang dibunuh, pastilah akan Ku-hapuskan kesalahan-kesalahan mereka dan pastilah aku masukkan mereka ke dalam surga yang mengalir sungai-sungai di bawahnya, sebagai pahala di sisi Allah. dan Allah pada sisi-Nya pahala yang baik."

Sifat penting dari konsep pengetahuan dalam Alquran adalah holistik dan utuh (berbeda dengan konsep sekuler tentang pengetahuan). Pembedaan ini sebagai bukti worldview tauhid dan monoteistik yang tak kenal kompromi. Dalam konteks ini berarti persoalan-persoalan epistemologis harus selalu dikaitkan dengan etika dan spiritualitas. (Dalam Islam) ruang lingkup persoalan epistemologis meluas, baik dari wilayah (yang disebut) bidang keagamaan dengan wilayah-wilayah (yang disebut sekuler), karena worldview Islam tidak mengakui adanya perbedaan mendasar antara wilayah-wilayah ini. Adanya pembedaan semacam itu akan memberi implikasi penolokan hikmah dan petunjuk Allah SWT, dan hanya memberi perhatian dalam wilayah tertentu saja. Wujud Allah SWT sebagai sumber semua pengetahuan, secara langsung meliputi kesatuan dan integralitas semua sumber dan tujuan epistemologis. Ini menjadi jelas jika kita merenungkan kembali istilah ayat yang menunjuk pada ayat-ayat Alquran dan semua wujud di alam semesta.

Konsep integralitas pengetahuan telah diuraikan al-Ghazali dalam kitabnya Jawahir Alquran, di mana ia menegaskan bahwa ayat-ayat Alquran yang menguraikan tentang bintang dan kesehatan, misalnya, hanya sepenuhnya dipahami masing-masing dengan pengetahuan astronomi dan kesehatan. Ibnu Rusyd dalam fasl al-maqal, juga memberikan penjelasan keterkaitan antara penafsiran keagamaan dan kefilsafatan dengan mengutip beberapa ayat Alquran yang mendorong manusia meneliti dan menggambarkan kajian penciptaan langit dan bumi, dalam ayat-ayat berikut.

QS Al A'raaf ayat 185:

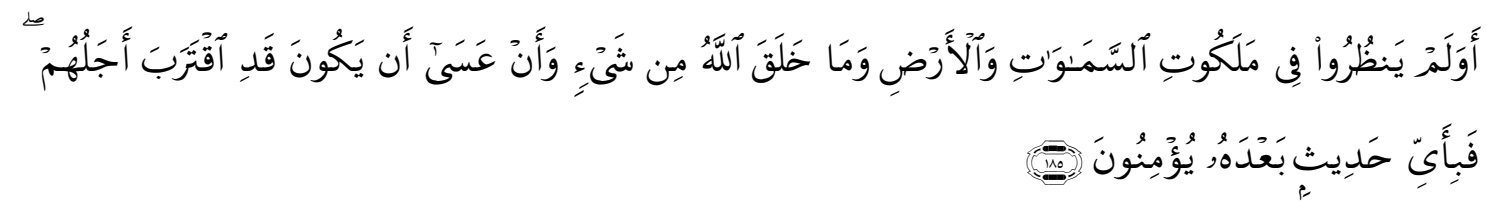

Artinya :"dan Apakah mereka tidak memperhatikan kerajaan langit dan bumi dan segala sesuatu yang diciptakan Allah, dan kemungkinan telah dekatnya kebinasaan mereka? Maka kepada berita manakah lagi mereka akan beriman sesudah Al Quran itu?”

QS Ali Imran ayat 191:

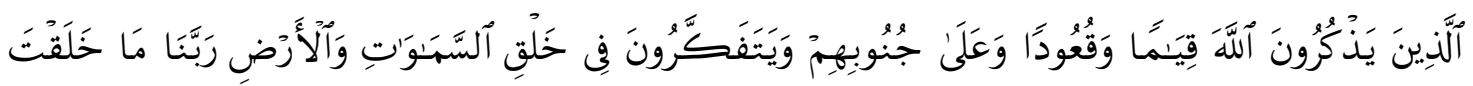

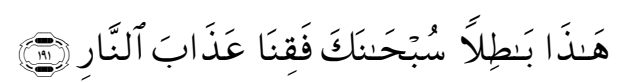


Artinya :"(yaitu) orang-orang yang mengingat Allah sambil berdiri atau duduk atau dalam keadan berbaring dan mereka memikirkan tentang penciptaan langit dan bumi (seraya berkata): "Ya Tuhan Kami, Tiadalah Engkau menciptakan ini dengan sia-sia, Maha suci Engkau, Maka peliharalah Kami dari siksa neraka”.

QS Al Ghaasiyyah ayat 17-18:

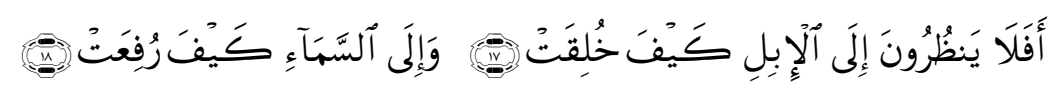

Artinya :"Maka Apakah mereka tidak memperhatikan unta bagaimana Dia diciptakan, dan langit, bagaimana ia ditinggikan?”

Dengan hal yang sama, Alquran juga mendorong manusia melakukan perjalanan di bumi untuk mempelajari nasib peradaban sebelumnya. Ini membentuk kajian sejarah, arkeologi, perbandingan agama, sosiologi dan sebagainya secara utuh.

Dalam QS Fushshilat ayat 53, secara kategoris, Alquran menegaskan bahwa ayat-ayat Allah SWT di alam semesta dan di kedalaman batin manusia merupakan bagian yang berkaitan dengan kebenaran wahyu, dan menegaskan kecocokan dan keutuhan yang saling terkait. Namun, keutuhan dan kesatuan cabang-cabang pengetahuan ini tidak berarti bahwa disiplin-disiplin itu sama, atau tidak ada prioritas diantara mereka.

QS Fushshilat ayat 53:

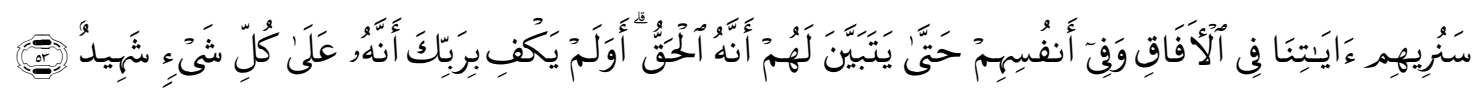

Artinya: Kami akan memperlihatkan kepada mereka tanda-tanda (kekuasaan) Kami di segala wilayah bumi dan pada diri mereka sendiri, hingga jelas bagi mereka bahwa Al Quran itu adalah benar. Tiadakah cukup bahwa Sesungguhnya Tuhanmu menjadi saksi atas segala sesuatu?

Pengetahuan wahyu dalam konsep Islam adalah lebih utama, unik karena berasal langsung dari Allah SWT dan memiliki manfaat yang mendasar bagi alam semesta. Semua pengetahuan lain yang benar harus membantu kita memahami dan menyadari arti dan jiwa pengetahuan Allah SWT di dalam Alquran untuk kemajuan individu dan masyarakat.

\section{Ilmu Pengetahuan dalam Hadits}

Hadits-hadits Nabi juga sangat banyak yang mendorong dan menekankan, bahkan mewajibkan kepada umatnya untuk menuntut ilmu (Alavi, 2003). Sebagaimana Sabda Rasulullah SAW:

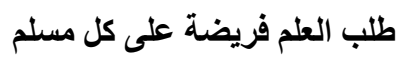

Artinya: “Menuntut ilmu itu suatu kewajiban kepada setiap muslim.” (HR. Ibnu Majah)

Hadits di atas memberikan dorongan yang sangat kuat bagi kaum muslimin untuk belajar mencari ilmu sebanyak-banyaknya, baik ilmu-ilmu agama maupun ilmu-ilmu umum, karena suatu perintah kewajiban tentunya harus dilaksanakan, dan berdosa hukumnya jika tidak dikerjakan. Lebih 
lanjut Rasulullah mewajibkan kepada umatnya untuk menuntut ilmu sepanjang hayatnya, tanpa di batasi usia, ruang, waktu dan tempat sebagaimana sabdanya "Tuntutlah ilmu dari buayan sampai liang lahat" dan "Tuntutlah ilmu sekalipun ke negeri Cina".

Dalam Media Islamika (2007), dorongan dari Alquran dan perintah dari Rasulullah tersebut telah dipraktikkan oleh generasi Islam pada masa abad pertengahan (abad ke 7-13 M). Hal ini terbukti dengan banyaknya ilmuan-ilmuan Muslim tampil kepentas dunia ilmu pengetahuan, sains dan teknologi, seperti Al-Farabi, Al-Kindi, Ibnu Sina, Ikhwanusshafa, Ibn Miskwaih, Nasiruddin al-Thusi, Ibn rusyd, Imam al-Ghazali, Al-Biruni, Fakhrudin ar-Razy, Imam Hanafi, Imam Malik, Imam Syafi'i, Imam Hambali dan lain-lain. Ilmu yang mereka kembangkanpun berbagai macam disiplin ilmu, bahkan meliputi segala cabang ilmu yang berkembang pada masa itu, antara lain: ilmu Filsafat, Fisika, Astronomi, Astrologi, Alkemi, Kedokteran, Optik, Farmasi, Tasauf, Fiqih, Tafsir, Ilmu Kalam dan sebagainya.

Pada masa itu kejayaan, kemakmuran, kekuasaan dan politik berada di bawah kendali umat Islam, karena mereka meguasai sains, ilmu pengetahuan dan teknologi. Rasululullah SAW pernah bersabda: "Umatku akan jaya dengan ilmu dan harta". Banyak lagi hadits-hadits beliau yang memberikan anjuran dan motivasi kepada umatnya untuk belajar menuntut ilmu, namun dalam kesempatan ini tentunya tidak dapat disebutkan semuanya.

\section{PENUTUP}

Dengan demikian, Alquran dan Hadits merupakan sumber ilmu yang dikembangkan oleh umat Islam dalam spektrum yang seluas-luasnya. Lebih lagi, kedua sumber pokok Islam ini memainkan peran ganda dalam penciptaan dan pengembangan ilmu-ilmu. Peran itu adalah: Pertama, prinsipprinsip semua ilmu dipandang kaum Muslimin terdapat dalam Al Qur'an. Dan sejauh pemahaman terhadap Alquran, terdapat pula penafsiran yang bersifat esoteris terhadap kitab suci ini, yang memungkinkan tidak hanya pengungkapan misteri-misteri yang dikandungnya tetapi juga pencarian makna secara lebih mendalam, yang berguna untuk pembangunan paradigma ilmu. Kedua, Alquran dan Hadits menciptakan iklim yang kondusif bagi pengembangan ilmu dengan menekankan kebajikan dan keutamaan menuntut ilmu, pencarian ilmu dalam segi apa pun pada akhirnya akan bermuara pada penegasan Tauhid. Karena itu, seluruh metafisika dan kosmologi yang lahir dari kandungan Alquran dan Hadits merupakan dasar pembangunan dan pengembangan ilmu Islam. Singkatnya, Alquran dan Hadits menciptakan atmosfir khas yang mendorong aktivitas intelektual dalam konformitas (Azra, 2001). Wahyu yang diterima oleh Nabi Muhammad SAW berasal dari Allah SWT, merupakan sumber pengetahuan yang paling pasti. Namun, Alquran juga menunjukkan sumber-sumber pengetahuan lain disamping apa yang tertulis di dalamnya, yang dapat melengkapi kebenaran wahyu. Pada dasarnya sumber-sumber itu diambil dari sumber yang sama, yaitu Allah SWT, asal segala sesuatu. Namun, karena pengetahuan yang tidak diwahyukan tidak diberikan langsung oleh Allah SWT kepada manusia, dan karena keterbatasan metodologis dan aksiologis dari ilmu non-wahyu tersebut, maka ilmu-ilmu tersebut di dalam Islam memiliki kedudukan yang tidak sama dengan ilmu pengetahuan yang langsung diperoleh dari wahyu. Sehingga, di dalam Islam tidak ada satupun ilmu yang berdiri sendiri dan terpisah dari bangunan epitemologis Islam, ilmu-ilmu tersebut tidak lain merupakan bayan atau penjelasan yang mengafirmasi wahyu, yang kebenarannya pasti. Di sinilah letak perbedaan epistemologi sekuler dengan epistemologi Islam. 


\section{DAFTAR PUSTAKA}

Abqary, R. (2010). 101 info tentang ilmuan muslim. Bandung: DAR! Mizan.

Alavi, Z. (2003). Pemikiran pendidikan Islam pada abad klasik dan pertengahan. Bandung: Angkasa.

Al-Indunisi, A. N. A. S. (2008). Ensiklopedia Imam Syafi'i. Jakarta: Hikmah.

Azra, A. (2001). Pendidikan Islam: Tradisi dan modernisasi menuju milenium baru (3rd ed.). Jakarta: Kahinah.

Baiquni, A. (1997). Alquran dan ilmu pengetahuan kealaman. Yogyakarta: Dana Bakhti Prima Yasa.

DEPAG. (2000). Sains menurut perespektif Alquran. Jakarta: Dwi Rama.

Gordon, S. (2008). Asia menguasai dunia. Jakarta: Cahaya Insan Suci.

Hafidhuddin, D. (1998). Dakwah actual. Jakarta: Gema Insani Press.

Hasan, M. T. (2005). Prospek Islam dalam menghadapi tantangan zaman. Jakarta: Lantabora Press.

Kartanegara, M. (2006). Reaktualisasi tradisi ilmiah Islam. Jakarta: Baitul Ihsan.

Media Islamika. (2007). Jurnal Kedokteran, Kesehatan dan Keislaman Fak. Kedokteran dan Ilmu Kesehatan UIN S Jakarta. MI, Vol. 4, No. 1, Mei 2007.

Rahardjo, M. D. (2002). Ensiklopedi Alquran tafsir sosila berdasarkan konsep-konsep kunci. Jakarta: Paramadina.

Sarwar, H. G. (1994). Filsafat Alquran. Jakarta: Raja Grafindo Persada.

Turner, H. R. 2004. Sains Islam yang mengagungkan sebuah catatan terhadap abad pertengahan. Bandung: Nuansa Bandung.

Yatim, B. (1997). Sejarah peradaban Islam. Jakarta: Raja Grafindo Persada. 